\title{
ANALISIS PENURUNAN MISKONSEPSI SISWA PADA KONSEP PEMANASAN GLOBAL DENGAN TES DIAGNOSTIK (TWO-TIER TEST) SETELAH PEMBELAJARAN PREDICT-OBSERVE-EXPLAIN (POE)
}

\author{
Ismi Ghina Suryawirawati ${ }^{1)}$, Billyardi Ramdhan ${ }^{2)}$, Aa Juhanda ${ }^{3)}$ \\ ${ }^{1)}$ Mahasiswa Program Studi Pendidikan Biologi \\ ${ }^{2,3)}$ Dosen Program Studi Pendidikan Biologi Universitas Muhammadiyah Sukabumi \\ e-mail: ismighina2017@gmail.com
}

\begin{abstract}
ABSTRAK
Masalah dalam penelitian ini adalah siswa mengalami kesulitan dalam memahami konsep, terutama pada konsep pemanasan global karena merupakan salah satu materi yang sulit dan ada beberapa konsep yang dianggap abstrak oleh siswa, sehingga dapat menimbulkan persepsi yang berbeda oleh siswa serta dapat menimbulkan miskonsepsi. Penelitian ini bertujuan untuk mengidentifikasi miskonsepsi siswa menggunakan tes diagnostik (two-tier test) setelah pembelajaran model predict-observe-explain (POE), kemudian menganalisis penurunan miskonsepsi siswa. Penelitian ini dilaksanakan di SMPN 5 Kota Sukabumi. Penelitian ini merupakan penelitian deskriptif dengan desain penelitian one-group-pretest-posttest Design. Sampel yang digunakan diambil dari populasi dengan teknik purposive sampling, yaitu kelas VII A dengan jumlah sampel sebanyak 41 orang. Teknik pengumpulan data dilakukan dengan tes diagnostik (twotier test) yaitu soal pilihan ganda dengan dua tahap pemilihan jawaban, dan lembar observasi. Instrumen soal terdiri dari 10 soal masing-masing dengan 3 pilihan jawaban dan 4 pilihan alasan. Hasil penelitian menunjukkan bahwa terdapat miskonsepsi pada saat pretest. Penurunan miskonsepsi siswa setelah pembelajaran model POE adalah rata-rata $66 \%$ dan tiap konsep adalah $64,98 \%$. Hasil penelitian dapat disimpulkan bahwa pada pembelajaran POE ini dapat dijadikan atlternatif pembelajaran untuk mengurangi miskonsepsi dapat dilihat dari nilai siswa antara sebelum pembelajaran (pretest) dan setelah pembelajaran posttestyangmenunjukkan penurunan miskonsepsi.
\end{abstract}

Kata Kunci: Tes Diagnostik (Two-Tier Test), ModelPredict-Observe-Explain(POE), Miskonsepsi, Pemanasan Global 


\begin{abstract}
The problem in this study is that students have difficulties in understanding the concept, especially on the concept of global warming because it is one of the hard material and there are some concepts that are considered abstract by the students, so it can cause different perception by the students and can cause misconception. This study aims to identify students' misconceptions using a two-tier test on learning predictobserve-explain (POE) models, then to analyze the decrease in student misconception. This research was conducted in SMPN 5 Sukabumi. This research is a descriptive research with one-group-pretest-posttest design research design. The sample used is taken from the population by purposive sampling technique, namely class VII A with the number of samples of 41 students. Data collection techniques were performed with a two-tier test (diagnostic) which was a multiple choice question with two stages of selection of an answer, and an observation sheet. The question instrument consists of 10 questions each with 3 answer choices and 4 choice of reasons. The results show that there are misconceptions at the time of pretest. The decrease in student misconception on learning POE model is an average of $66 \%$ and each concept is $64,98 \%$. The result of this research can be concluded that the learning of POE can be used as an alternative to learning to reduce misconception can be seen from the students score between before learning (pretest) and after posttest learning which shows the decrease of misconception.
\end{abstract}

Keywords: Two-Tier Test, Predict-Observe-Explain Model (POE), Misconception, Global Warming

\title{
PENDAHULUAN
}

Pemahaman pada konsep tentunya akan berbeda-beda antara siswa satu dengan siswa yang lainnya, terlebih bagaimana mereka dapat menyerap informasi yang diperoleh dengan pemahaman konsep awal atau yang disebut dengan prakonsepsi. Namun terkadang ada kesalahan konsep pada prakonsepsi yang dimiliki oleh siswa, baik itu secara keilmuan maupun terkendala dalam proses penyerapan informasi yang salah. Keadaan ini tentunya tidak hanya dipengaruhi proses pengajaran dari guru, seperti pemilihan metode, model, ataupun yang lainnya. Sebagian hal seperti penyampaian materi pelajaran dengan menggunakan model pembelajaran yang melibatkan siswa untuk aktif, agar siswa tidak merasa bosan, jenuh, dan tertarik untuk belajar, sehingga hasil belajar dapat diperoleh secara maksimal.

Pembelajaran akhir biasanya guru akan bertanya mengenai materi yang dipelajari, namun terkadang siswa menjawab tidak sesuai dengan konsep yang ada, ini termasuk ke dalam miskonsepsi. Miskonsepsi mencakup: 1) pengertian yang tidak akurat tentang konsep, 2) penggunaan konsep yang salah, 3) klasifikasi contoh-contoh yang salah tentang penerapan konsep, 4) pemaknaan konsep yang berbeda, 5) 
kekacauan konsep-konsep yang berbeda, dan 6) hubungan hierarkis konsep-konsep yang tidak benar (Suparno, 2005).

Sebagai upaya mengetahui penyebab dan mengatasi miskonsepsi tersebut perlu adanya penelitian, salah satunya adalah dengan menganalisis miskonsepsi dan penurunan miskonsepsi dengan memberikan soal berupa tes diagnostik (two-tier test) menggunakan suatu model yang tepat. Pembelajaran IPA di sekolah kini sudah beragam menggunakan berbagai metode, dan model karena kurikulum yang digunakan adalah kurikulum 2013 yang menekankan pada aspek sikap, pengetahuan, dan keterampilan.

Banyak penelitian dilakukan untuk menyelidiki miskonsepsi pada siswa. Misalnya remediasi miskonsepsi tentang gaya sentripetal dan gaya sentripugal pada gerak melingkar beraturan menggunakan metode demonstrasi sederhana (Wulandari, 2014), menunjukkan bahwa metode pembelajaran yang digunakan yaitu metode demonstrasi sederhana, dapat meremediasi siswa yang mengalami miskonsepsi tentang gaya sentripetal dan gaya sentripugal pada gerak melingkar beraturan, metode ini digunakan sebagai salah satu metode yang dapat meremediasi miskonsepsi siswa. Penelitian selanjutnya mengenai remediasi miskonsepsi siswa tentang GMB menggunakan metode demonstrasi berbantuan guided note taking di SMA. Rosita (2012) menjelaskan bahwa total rata-rata penurunan miskonsepsi siswa tiap konsep sebesar $9,17 \%$.

Salah satu kegiatan pembelajaran yang dapat membangun konsepsi siswa adalah dengan siswa menemukan terlebih dahulu pengetahuannya, dan ternyata model pembelajaran Predict-Observe-Explain (POE) ini sangat baik, siswa dilibatkan untuk memprediksi pengetahuan awal, terlibat langsung dengan melakukan observasi, dan menjelaskan hasil penemuannya. POE digunakan untuk mengidentifikasi dan mengatasi miskonsepsi siswa, karena memungkinkan siswa untuk berhipotesis, menguji hipotesis mereka, dan menjelaskan pengamatan (Kibirige dan Osodo, 2014). Maka dari itu model pembelajaran POE ini membantu guru untuk mengidentifikasi miskonsepsi pada siswa tentang ilmu pengetahuan yang ada, dan mencari solusi untuk mengatasi masalah miskonsepsi tersebut. Kelebihan model pembelajaran POE ini adalah siswa tidak hanya diajak untuk mengamati saja tetapi siswa dituntut aktif mencari pengetahuan dan berpikir kritis. Siswa diajak untuk berpikir kritis dengan 
kemungkinan yang mereka dapatkan pada saat pembelajaran dan berhipotesis terhadap masalah yang mereka dapatkan ketika pembelajaran.

Maka dari itu peneliti bermaksud menggunakan metode tes diagnostik pilihan ganda beralasan (two tier test) untuk mengungkap miskonsepsi siswa, berbantuan menggunakan model POE pada konsep pemanasan global. Diharapkan dapat membangun konsep siswa, memperbaiki miskonsepsi sebelumnya, dan siswa pada saat pembelajaran merasa tidak jenuh, karena siswa dilibatkan untuk aktif membangun konsep melalui kegiatan melihat, mendengar, dan terlibat langsung (praktikum) dalam pembelajaran, sehingga miskonsepsi awal yang dibawa siswa sebelumnya dapat menurun.

\section{METODE PENELITIAN}

Dalam penelitian ini digunakan desain One-Group-Pretest-Posttest Design. Design ini terdapat pretest sebelum diberi perlakuan, sehingga hasil perlakuan lebih akurat karena dapat membandingkan dengan keadaan setelah diberi perlakuan atau posttest. Desain ini dapat digambarkan pada Tabel 1.

Tabel 1 One-Group-Pretest-Posttest Design

\begin{tabular}{ccc}
\hline Pretest & Perlakuan & Posttest \\
\hline $\mathrm{O}_{1}$ & $\mathrm{X}$ & $\mathrm{O}_{2}$ \\
\hline
\end{tabular}

(Arikunto, 2013)

Keterangan :

$\mathrm{O}_{1}=$ nilai pretest (dilakukan sebelum eksperimen)

$\mathrm{O}_{2}=$ nilai posttest (observasi sesudah eksperimen)

$\mathrm{X}=$ perlakuan

$\mathrm{O}_{2}-\mathrm{O}_{1}=$ diasumsikan merupakan efek dari treatment atau eksperimen

Sampel diambil dengan menggunakan teknik pengambilan sampel secara purposive sampling yaitu pengambilan sampel sumber data dengan pertimbangan tertentu, diharapkan sehingga akan memudahkan peneliti menjelajahi obyek/situasi sosial yang diteliti (Sugiyono, 2010). Sampel ini diambil dari populasi siswa kelas VII SMPN 5 Kota Sukabumi, yang terdiri dari VII A, VII B, VII C, dan VII D tahun ajaran 2017/2018 dengan jumlah siswa setiap kelasnya sebanyak 44 orang. Sampel dipilih sesuai dengan kebutuhan penelitian dengan pertimbangan tertentu, dan kelas yang dijadikan sampel pada penelitian ini adalah VII A dengan jumlah siswa sebanyak 44. 
Alat ukur dalam penelitian dinamakan dengan instrumen penelitian. Instrumen penelitian yang digunakan adalah tes diagnostik (two-tier test) Tes ini bertujuan untuk mengetahui ada tidaknya miskonsepsi dengan soal pilihan ganda beserta pilihan alasan yang terdiri dari 3 pilihan jawaban yaitu jika siswa menjawab pilihan beserta alasan benar maka skor (1), jika jawaban benar alasan salah atau jawaban salah alasan benar maka skor (0), dan jika jawaban beserta alasan salah maka skor (0), dan lembar observasi digunakan untuk melihat aktivitas dari model pembelajaran predict-observeexplain (POE).

Instrumen penelitian divalidasi dengan pengujian validitas butir soal menggunakan validitas isi (content validity) korelasi product moment dengan angka kasar yang dikemukakan oleh Pearson pada SPSS 24. Dari 12 butir soal yang validitasnya memenuhi syarat adalah 10 soal dengan nilai signifikansi 0,05. Pengujian reliabilitas menggunakan SPSS 24 rumus cronbach's alpha dengan rata-rata tingkat reliabilitas soal sebesar 0,675 dan dinyatakan reliabel, karena $r$ hitung $>r$ tabel. Uji coba instrumen dilakukan di kelas VIII D berjumlah sebanyak 43 siswa. Kemudian selanjutnya dihitung tingkat kesukaran soal dengan rata-rata soal sedang dan mudah, dan yang terakhir adalah dengan menguji daya pembeda soal dengan membandingkan $r$ hitung dengan $r$ tabel.

Adapun prosedur penelitian yang akan dilaksanakan terdiri dari tahapan persiapan, tahap pelaksanaan, dan tahap analisis data penelitian (akhir), dapat dijelaskan yaitu:

\section{Tahap Persiapan}

Tahap persiapan ini diantaranya adalah melakukan observasi ke sekolah yang dituju, tujuannya untuk menentukan subjek dan waktu perlakuan dilakukan, mengurus surat riset/penelitian, mempersiapkan instrumen penelitian, uji coba instrumen dan didapatkan instrument yang telah di validasi.

\section{Tahap Pelaksanaan}

Tahap pelaksanaan ini yaitu: memberikan tes awal (pretest) untuk menggali konsepsi siswa yang mengindikasikan miskonsepsi, memberikan kegiatan pembelajaran model predict-observe-explain (POE), memberikan tes akhir (posttest). Pada tahap pelaksanaan ini lembar observasi diisi oleh 2 orang guru sebagai observer untuk melihat kegiatan pembelajaran siswa dengan model POE. 


\section{Tahap Akhir}

Tahap akhir ini terdiri dari: mengolah jawaban siswa berdasarkan kategori tingkat pemahaman siswa sebelum (pretest)dan setelah (posttest), menghitung jumlah kesalahan siswa pada tiap konsep sebelum dan setelah dilaksanakan pembelajaran untuk mengindikasikan miskonsepsi siswa, menghitung rata-rata penurunan miskonsepsi siswa tiap konsep, dan penurunan jumlah miskonsepsi tiap siswa.

\section{HASIL DAN PEMBAHASAN}

Penelitian ini dilaksanakan pada siswa kelas VII SMPN 5 Kota Sukabumi tahun ajaran 2017/2018. Siswa yang menjadi subjek dalam penelitian ini adalah kelas VIIA yang berjumlah 44 siswa, namun yang terhitung hanya 41 siswa, karena ada beberapa siswa yang tidak hadir dalam pertemuan 1, 2 dan 3 sebanyak 3 siswa.

Pembelajaran POE ini dapat menurunkan jumlah miskonsepsi siswa, dapat dilihat dari perbandingan antara pretest dan posttest dengan soal yang diberikan sebanyak 10 soal pilihan ganda beralasan (two-tier test). Waktu pelaksanan dimulai dari 4 April 2018-18 April 2018. Penelitian ini dibagi menjadi beberapa pertemuan, yaitu pada pertemuan pertama 4 April 2018 dengan subkonsep mengenai efek rumah kaca dengan melakukan praktikum, kemudian memberikan soal pretest dan posttest yang sama sebanyak 3 soal, pertemuan kedua dilaksanakan pada 7 April 2018 dengan subkonsep mengenai pengertian, penyebab dan dampak pemanasan global dengan melakukan pembelajaran cukup dikelas, kemudian memberikan soal pretest dan posttest yang samasebanyak 5 soal, dan pertemuan terakhir dilaksanakan pada 18 April 2018 dengan subkonsep usaha penanggulangan pemanasan global dengan melakukan pembelajaran praktikum, kemudian memberikan soal pretest dan posttest yang sama sebanyak 2 soal, sehingga total soal yang diberikan kepada siswa berjumlah 10 soal.

Pelaksanaan penelitian ini melibatkan guru sebagai observer dalam menilai kegiatan siswa selama pembelajaran dengan model POE, di awal pembelajaran peneliti memberikan soal pretest terlebih dahulu untuk melihat miskonsepsi siswa sebelum dilakukan pembelajaran model POE, kedua peneliti melaksanakan pembelajaran dengan model POE dan yang terakhir peneliti memberikan posttest sebagai langkah untuk melihat penurunan miskonsepsi siswa.

Jawaban siswa dianalisis dengan 3 pilihan jawaban, yaitu siswa dikatakan benar jika menjawab pertanyaan atau pernyataan dan alasan benar, siswa dikatakan salah jika 
menjawab pertanyaan benar dan alasan salah atau sebaliknya jika siswa menjawab pertanyaan atau pernyataan salah dan alasan salah maka dapat dikatakan jawaban tersebut adalah salah.Kemudian setelah itu menghitung jumlah kesalahan siswa pada tiap konsep sebelum dan setelah dilaksanakan pembelajaran untuk mengindikasikan miskonsepsi siswa,

Adapun hasil dari analisis uji proporsi penurunan rata-rata miskonsepsi siswa tiap konsep sebesar 64,98\%, dapat dilihat pada Tabel 2. Persentase rata-rata penurunan miskonsepsi siswa tiap konsep menunjukan 64,98\%, angka ini cukup baik jika dibandingkan sebelum dilakukannya pembelajaran POE.

Tabel 2. Penurunan Miskonsepsi Siswa Tiap Konsep

\begin{tabular}{ccccc}
\hline $\begin{array}{c}\text { No } \\
\text { Butir } \\
\text { Soal }\end{array}$ & \multicolumn{2}{c}{ Frekuensi } & $\begin{array}{c}\text { Penurunan } \\
\text { Miskonsepsi }\end{array}$ & $\begin{array}{c}\text { Persentase Penurunan } \\
\text { Miskonsepsi }\end{array}$ \\
\hline 1 & 3 & 1 & 0.66 & $66.66 \%$ \\
\hline 2 & 6 & 0 & 1 & $100 \%$ \\
\hline 3 & 2 & 1 & 0.5 & $50 \%$ \\
\hline 4 & 13 & 4 & 0.69 & $69.23 \%$ \\
\hline 5 & 9 & 1 & 0.88 & $88.88 \%$ \\
\hline 6 & 5 & 4 & 0.2 & $20 \%$ \\
\hline 7 & 6 & 3 & 0.5 & $50 \%$ \\
\hline 8 & 20 & 4 & 0.8 & $80 \%$ \\
\hline 9 & 4 & 1 & 0.75 & $75 \%$ \\
\hline 10 & 4 & 2 & 0.5 & $50 \%$ \\
\hline Persentase rata-rata penurunan miskonsepsi & $64.98 \%$ \\
\hline
\end{tabular}

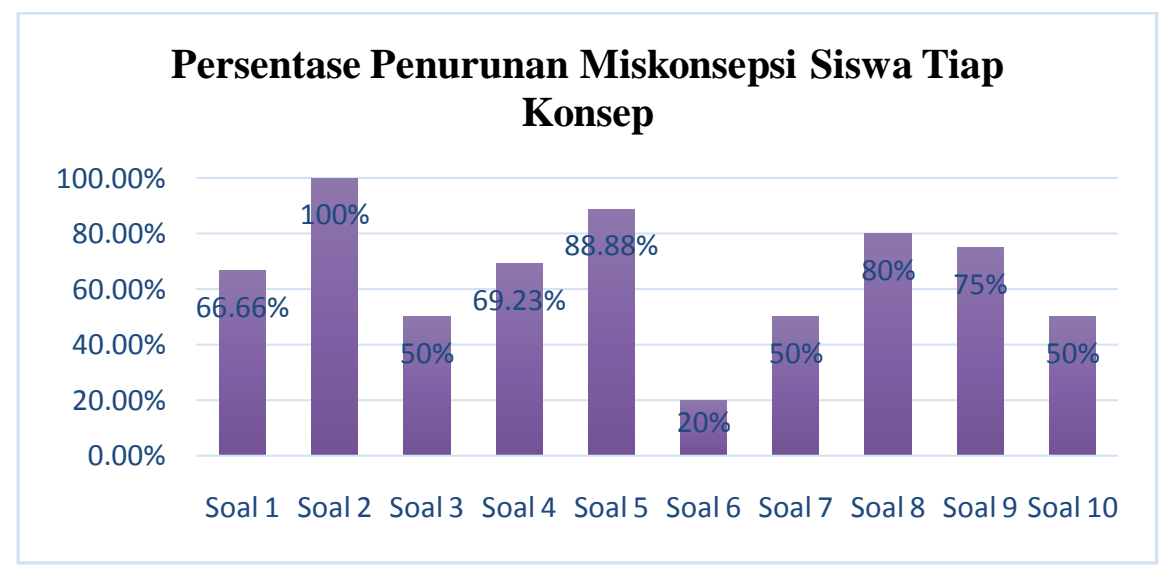

Gambar 1. Diagram Penurunan Miskonsepsi Siswa Tiap Konsep

Jika dilihat dari persentase penurunan paling besar terjadi pada nomor butir soal 2 yang masuk ke dalam subkonsep efek rumah kaca yaitu mengenai gas-gas yang dapat 
meningkatkan efek rumah kaca sebesar $100 \%$ yaitu dari $14,63 \%$ menjadi $0 \%$, dengan jumlah siswa yang miskonsepsi sebelumnya 6 siswa menjadi 0 siswa, yang artinya terjadi penurunan jumlah siswa yang miskonsepsi sebanyak 6 siswa. Kemudian untuk penurunan miskonsepsi siswa tiap konsep yang paling kecil penurunannya adalah pada nomor butir soal 2 yang masuk dalam subkonsep pengertian, penyebab dan dampak pemanasan global yaitu mengenai penyebab terjadinya pemanasan global sebesar $20 \%$ yaitu dari $12,19 \%$ menjadi $9,76 \%$ dengan jumlah siswa yang miskonsepsi sebelumnya adalah 5 siswa menjadi 4 siswa, yang artinya terjadi penurunan jumlah siswa yang miskonsepsi hanya sebanyak 1 siswa saja.

Hasil analisis untuk penurunan rata-rata jumlah miskonsepsi tiap siswa dilihat antara hasil pretest dan posttest yaitu 66\% dari jumlah siswa 41 yang terjadi miskonsepsi adalah sebanyak 35 siswa, karena 6 siswa lainnya tidak terjadi miskonsepsi yaitu no absen 1,7,9,15,19, dapat dilihat pada Tabel 3 dan Gambar 2.

Tabel 3. Penurunan Jumlah Miskonsepsi Tiap Siswa

\begin{tabular}{cc}
\hline Jumlah Siswa & Persentase Penurunan jumlah Miskonsepsi Tiap Siswa (\%) \\
\hline 6 & Tidak terjadi miskonsepsi \\
\hline 21 & Terjadi penurunan miskonsepsi 100\% \\
\hline 1 & Terjadi penurunan miskonsepsi 75\% \\
\hline 5 & Terjadi penurunan miskonsepsi 66.66\% \\
\hline 2 & Terjadi penurunan miskonsepsi 50\% \\
\hline 2 & Terjadi kenaikan miskonsepsi \\
\hline 4 & Tidak Terjadi penurunan miskonsepsi \\
\hline Rata-rata & $66 \%$ \\
\hline
\end{tabular}

Persentase rata-rata penurunan miskonsepsi tiap siswa menunjukkan $66 \%$ angka yang cukup baik karena lebih 50\% siswa mengalami penurunan miskonsepsi dibandingkan sebelum pembelajaran POE. Berdasarkan tabel 2 telah terjadi penurunan miskonsepsi sebesar 100\% setelah pembelajaran POE (posttest) yaitu sebanyak 21 siswa, 1 siswa terjadi penurunan miskonsepsi sebesar 75\%, 5 siswa terjadi penurunan sebanyak 66,66\%, 2 siswa terjadi penurunan miskonsepsi sebesar 50\%, namun selain itu terjadi kenaikan miskonsepsi pada beberapa siswa yaitu 2 siswa mengalami kenaikan miskonsepsi $-100 \%$ atau 2 kali lipat dari miskonsepsi sebelumnya yaitu siswa dengan nomor absen 8 , sebelumnya pada pretestterjadi miskonsepsi sebanyak 1 soal, 
kemudian setelah pembelajaran (posttest) menjadi 2, ini artinya mengalami penambahan miskonsepsi. Selain siswa dengan nomor absen 8 , pada siswa dengan nomor absen 27 mengalami kenaikan miskonsepsi, sebelumnya siswa tersebut terjadi miskonsepsi sebanyak 1 soal, namun kemudian setelah pembelajaran terjadi miskonsepsi sebanyak 3 soal, yang artinya mengalami kenaikan miskonsepsi 3 kali lipat atau $-200 \%$. Selanjutnya ada juga siswa yang tidak mengalami penurunan miskonsepsi sama sekali yaitu pada siswa dengan nomor absen 3,5,17 dan 38 .

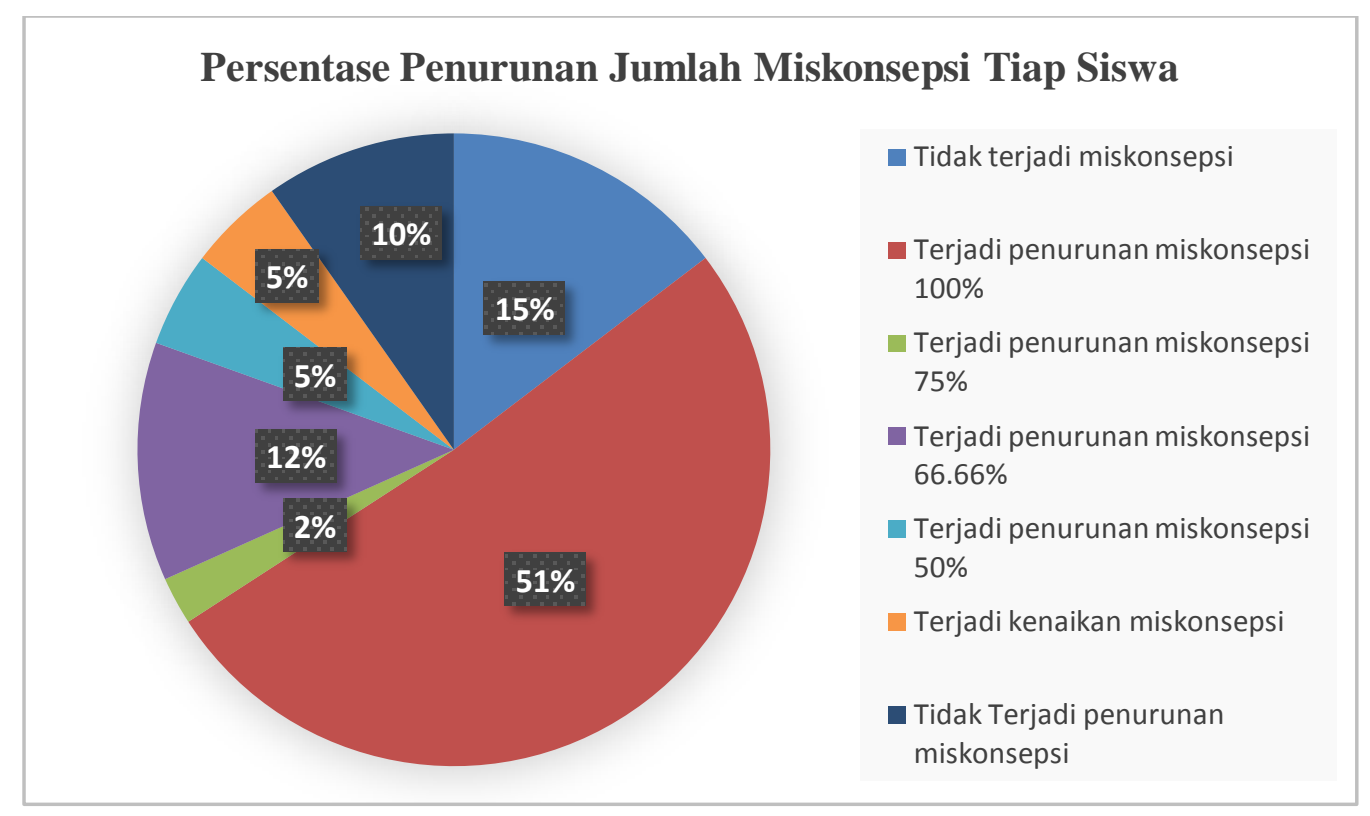

Bagan 2. Diagram Penurunan Jumlah Miskonsepsi Tiap Siswa

Hasil penelitian menunjukkan bahwa dengan adanya pembelajaran dengan model predict-observe-explain (POE) dapat menurunkan miskonsepsi siswa, baik miskonsepsi tiap konsep maupun miskonsepsi tiap siswa. Hal ini dapat dilihat dari perbedaan antara sebelum dilakukan pembelajaran POE (pretest) dan sesudah pembelajaran POE (posttest) yang berpengaruh dalam menurunkan miskonsepsi siswa. Penurunan miskonsepsi siswa tiap konsep rata-rata sebesar 64,98\%. Hasil yang sama juga ditemukan oleh Novika Lestari (2014), yaitu dengan penggunaan tes diagnostik sebagai instrumentes dalam penurunan miskonsepsi menggunakan pembelajaran multimedia interaktif dapat menurunkan miskonsepsi siswa tiap konsep sebesar $44 \%$ dan penurunan miskonsepsi siswa tiap siswa sebesar $42,2 \%$. 
Penggunaan Tes Diagnostik (two-tier test) selain dapat menurunkan miskonsepsi siswa, namun dapat meningkatkan pemahaman konsep siswa, terbukti dengan adanya penelitian lain yang telah ditemukan oleh Sagap (2014), yaitu penggunaan pilihan ganda beralasan sebagai instrumen tes untuk mengukur pemahaman konsep siswa berdasarkan hasil yang diujikan didapatkan bahwa 26,79\% paham, 28,72\% miskonsepsi dan 44,495 tidak paham.

Model pembelajaran POE ini pertama kali diperkenalkan oleh Richard F. Gunstone dan Richard T.White (1981) dimana model pembelajaran ini dapat memfasilitasi perubahan konseptual siswa, karena tahapan-tahapan pembelajarannya sama dengan pendekatan secara kontruktivisme. Terutama jika pada pembelajaran IPA ini, siswa tidak hanya mengalami pembentukan konsep melalui teori saja, namun harus dengan upaya yang nyata, dengan melihat fenomena-fenomena dari apa yang mereka pelajari secara langsung.

Tahapan-tahapan POE diantaranya adalah pada tahap pertama adalah memprediksi (predict), yaitu guru menggali konseptual awal siswa dengan menyajikan suatu permasalahan yang nantinya siswa melakukan prediksi awal terhadap gejala yang akan didapatkan pada fenomena atau masalah yang disajikan oleh guru. Tahap kedua observasi (observe), yaitu guru memberikan kesempatan kepada siswa untuk membentuk pengetahuannya melalui kegiatan pengamatan seperti praktikum dan diskusi, disinilah terjadi rasa keinginan siswa dalam menggali atau mencari informasi dari fenomena yang sedang dipelajari. Tahap akhir dari POE ini adalah menjelaskan (explain), yaitu tahap dimana guru memberikan suatu penguatan terhadap fenomena yang telah siswa dapatkan dari kegiatannya.

Kegiatan yang dilakukan siswa pada pertemuan pertama dengan praktikum mengenai efek rumah kaca, karena materi ini dapat dianggap abstrak oleh siswa SMP, maka diadakan suatu kegiatan untuk membuktikan mengenai efek rumah kaca melalui pemodelan efek rumah kaca dengan cara membandingkan tabung A dan B yang sebelumnya dimasukan handuk hangat kemudian perbedaan tabung A ditutup dengan plastik dan B tidak, maka manakah yang temperaturnya lebih tinggi.

Kemudian siswa dapat membuktikan hasil prediksi mereka sebelumnya benar atau tidak. Setelah dianalisis pada pretest, siswapaling banyak mengalami miskonsepsi pada nomor soal 1 dan 3. Pada nomor 1, siswa beranggapan bahwa gas-gas rumah kaca 
di atmosfer bumi dapat mengakibatkan terjadinya gas-gas rumah kaca, hal ini tidak sesuai bahwa sebenarnya gas-gas rumah kaca dapat menyebakan terjadinya pemanasan global, namun setelah diadakan pembelajaran dengan POE, mereka dapat membuktikan bahwa ternyata gas-gas rumah kaca yang terperangkaplah yang dapat menyebabkan suhu lingkungan menjadi meningkat dan menyebabkan pemanasan global, hal ini juga berhubungan dengan soal nomor 3 mengenai efek rumah kaca yang diakibatkan oleh meningkatnya suhu lingkungan, dari kegiatan remediasi ini ternyata dapat menurunkan miskonsepsi siswa.

Seperti pada penelitian yang telah dilakukan pada siswa SMP kelas VII, karena bila dilihat dari cara pembentukan konsep, mereka masih bersifat partial, atau belum berpikir secara komprehensif (menangkap, menerima), banyaknya pengaruh dari luar ataupun dari diri siswa sendiri dapat berpengaruh terhadap pembentukan konsep siswa juga. Pada saat penelitian, sebagai seorang guru sekaligus peneliti, dapat dilihat ketika mereka mengerjakan soal yang ada, keadaan siswa ada yang tidak percaya diri dengan jawabannya sendiri, dapat dipengaruhi juga dari kesiapan siswa sebelum pembelajaran, ketika ditanya ada sebagian yang tidak mempelajari konsep yang akan disampaikan oleh guru sebelumnya, faktor kesiapan siswa dalam mencerna pelajaran juga berbeda, ada yang memperhatikan guru ketika mengajar dan ada pula yang tidak memperhatikan apa yang diajarkan oleh guru.

Hasil penelitian membuktikan bahwa model pembelajaran predict-observeexplain (POE) dapat juga meningkatkan aktivitas dan pemahaman konsep siswa di SMP, seperti Obimita Ika Permatasari (2017), dengan menerapkan model pembelajaran POE dikembangkan untuk mengetahui konsep siswa mengenai suatu konsep berbasis kontekstual, peningkatan pemahaman konsep di uji dengan uji gain untuk kelas eksperimen dan kelas control 0,53 dan 0,44 , keefektifan model pembelajaran yang digunakan adalah nilai posttestmendapatkan respon sebesar $86,65 \%$ dan dapat disimpulkan bahwa penerapan model POE berbasis kontekstual dapat meningkatkan aktivitas dan pemahaman konsep siswa serta efektif digunakan di dalam pembelajaran.

Faktor-faktor luar yang dapat mempengaruhi penelitian disebut juga variabel luar, maka dari itu masih ada beberapa siswa yang masih mengalami miskonsepsi bahkan ada yang miskonsepsinya tidak mengalami penurunan, hal ini karena tidak adanya variabel kontrol sebagai pembanding, yaitu hanya menggunakan satu kelas 
dalam melihat penurunan miskonsepsi. Penurunan miskonsepsi ini tidak terlepas dari jawaban siswa ketika sebelum pembelajaran dan setelah pembelajaran. Penggunaan tes diagnostik (two-tier test) salah satunya diperkenalkan oleh Treagust, D.F (2006), untuk menggali konsep siswa. Tes ini sangat efektif dalam menggali konsep siswa, sehingga dapat dilihat dari penurunan miskonsepsi siswa pada tiap konsep, yang artinya siswa mengalami kenaikan dalan pemahaman konsep mereka, dengan adanya pertanyaan disertai alasan, maka siswa tidak bisa sembarang menebak jawaban yang ada, dari situlah jawaban siswa dapat dikatan memahami dan tidak miskonsepsi jika pernyataan dengan alasan benar kedua-duanya.

Hasil penelitian menunjukkan bahwa siswa yang mengalami penurunan yang paling signifikan berjumlah 21 orang dari 41 siswa sebanyak 100\%. Terlihat hampir $50 \%$ siswa tersebut benar-benar mengalami penurunan miskonsepsi dengan sangat baik, selain itu juga beberapa siswa yang mengalami penurunan miskonsepsi dengan tingkat persentase $50 \%, 66,66 \%$ dan $75 \%$, sisanya ada yang tidak mengalami penurunan miskonsepsi, atau yang kemudian mengalami kenaikan tingkat miskonsepsi, namun ini hanya sebagian kecil. Faktor-faktor luar dan diri siswa dapat menjadi salah satu pemicu tidak terjadinya penurunan miskonsepsi atau kenaikan miskonsepsi. Hal tersebut dapat dikatakan bahwa penggunaan tes diagnostik (two-tier test) dan pembelajaran model POE dapat menyebabkan terjadinya penurunan miskonsepsi dengan baik.

\section{SIMPULAN}

Berdasarkan analisis dari penggunaan tes diagnostik (two-tier test) dan setelah pembelajaran model predict-observe-explain (POE) dalam menurunkan miskonsepsi siswa di kelas VII SMPN 5 Kota Sukabumi pada konsep pemanasan global, yaitu diantaranya (1) Persentase rata-rata penurunan miskonsepsi siswa rata-rata tiap konsep menunjukan 64,98\%, angka ini cukup baik jika dibandingkan sebelum dilakukannya pembelajaran POE, (2) Persentase rata-rata penurunan miskonsepsi tiap siswa menunjukkan 66\% angka yang cukup baik karena lebih 50\% siswa mengalami penurunan miskonsepsi dibandingkan sebelumnya pembelajaran POE, (3) Penggunaan tes diagnostik (two-tier test) dan pembelajaran model POE dapat menyebabkan terjadinya penurunan miskonsepsi dengan baik. 


\section{DAFTAR PUSTAKA}

Arikunto, S. (2013). Prosedur Penelitian Suatu Pendekatan Praktik. Jakarta: PT Rineka Cipta.

Lestari, Novika. Sutrisno, Leo dan Oktavianty, Erwina. (2014). Remediasi Miskonsepsi Menggunakan Multimedia Interaktif Guide Discovery Pada Tekanan Zat Cair Siswa SMP. Artikel Penelitian. Program Studi Pendidikan Fisika FKIP Untan.

Permatasari, Obimita Ika dan Putut Marwato. Penerapan Model Pembelajaran PredictObserve-Explain (POE) Berbasis Kontekstual untuk Meningkatkan Aktivitas dan Pemahaman Konsep Siswa SMP. Jurnal Ilmu Pendidikan Fisika Vol 2(2) September 2017 50-53.

Rosita. (2012). Remediasi Miskonsepsi Siswa Tentang GMB Menggunakan Metode Demonstrasi Berbantuan Guided Note Taking di SMA.(Skripsi). Program Studi Pendidikan Fisikan FKIP Untan.

Sagap, Sarjan dan Muchlis. (2014). Analisis Pemahaman Konsep Biologi Menggunakan Pilihan Ganda Beralasan dalam Materi Pokok Sel Pada Siswa Kelas XI IPA SMA Negeri 1 Dampal Selatan. Jurnal e-jipbiol Vol 2(3).

Sugiyono. (2010). Metode Penelitian Kuantitatif Kualitatif dan R\&D. Bandung: Alfabeta.

Suparno, P. (2005). Miskonsepsi dan Perubahan Konsep dalam Pendidikan Fisika. Yogyakarta: Grasindo.

Treagust, D. F (2006). Diagnostic assessment in science as a means to improving teaching, learning and retention. Uniserve Science Assessment Symposium Procedings.

Wulandari, Y. (2014). Remediasi Miskonsepsi Tentang Gaya Setripetal dan Gaya Sentripugal pada Gerak Melingkar Beraturan Menggunakan Metode Demonstrasi Sederhana. (Skripsi). Program Studi Pendidikan Fisika Fakultas Sains dan Matematika Universitas Kristen Satya Wacana. 